\title{
Fósturlát í kjölfar legvatnsástungu og fylgjusýnitöku á Íslandi
}

\author{
Kristín Rut Haraldsdóttir ${ }^{1,2}$ ljósmóðir, Helga Gottfreðsdóttir ${ }^{1,2}$ ljósmóðir, Reynir Tómas Geirsson ${ }^{2,3} æ k n i r$
}

\section{ÁGRIP}

Inngangur: Legvatnsástungur og fylgjusýnitökur (samheiti: legástungur) eru aðferðir til að skoða litningagerð fósturs. Punguðum konum 35 ára og eldri hefur í yfir 35 ár boðist að fá gerða legástungu. Aldur móður var aðalástæðan fram til ársins 1998 pegar ný fósturskimun, sampætt líkindamat, var innleidd mun fyrr í meðgöngu. Tilgangur rannsóknarinnar var að skoða afdrif pungana í kjölfar legástungu í einbura- og tvíburapungunum, einkum með tilliti til fósturláts, breytingar á aldurssamsetningu, ástæður fyrir legástungunni og niðurstöður litningarannsóknar.

Efniviður og aðferðir: Rannsóknin var afturskyggn og náði til íslenskra kvenna sem komu í legástungu $(n=2323)$ á fósturgreiningardeild kvennadeildar Landspítala á árunum 1998-2007. Skrár um fósturgreiningaraðgerðir og mæðra- og sjúkraskrár voru notaðar til að safna gögnum um ástæðu fyrir legástungu, aldur móður, hvort legvatnsástunga eđa fylgjusýni var valin, afdrif meðgöngu og litningagerð fósturs.
Niðurstöður: Legástungum fækkaði umtalsvert, úr tæplega 500 í rúmlega 100 í lok rannsóknartímabilsins. Fylgjusýnitökum fjölgaði hlutfallslega. Fósturlát tengd legástungu voru 22/2323(0,9\%). Ekki var marktækur munur eftir pví hvort gerð var legvatnsástunga $(0,8 \%)$ eða fylgjusýnitaka (1,3\%). Munurinn minnkaði i $0,7 \%$ og 0,8\% fyrir hvora greiningaraðferðina á seinni helmingi rannsóknartímabilsins. Aldurssamsetning varð dreifðari og aldursástæðum fækkaði úr 81,2\% niður i 30,8\%.

Ályktun: Tíonitölur um fósturlát við legástungur hér á landi reyndust sambærilegar pví sem er erlendis og fylgikvillar fátíđir. Með algengari fylgjusýnitökum færðist fósturgreining á fyrri stig meðgöngu. Ný skimun hefur breytt aldurssamsetningu og hún býðst nú öllum konum. Gögnin gefa færi á að bæta upplýsingagjöf og fræðslu til verðandi foreldra í tengslum við legástungur.
${ }^{1}$ Hjúkrunarfræðideild, ljósmóðurfræði, Háskóla Íslands, ${ }^{2}$ kvennadeild Landspítala, ${ }^{3} æ k$ nadeild Háskóla Íslands.

Fyrirspurnir: Kristín Rut Haraldsdóttir krruthar@landspitali.is

Greinin barst 23. ágúst 2013, sampykkt til birtingar 7. febrúar 2014

\section{Inngangur}

Legástungur hafa verið notaðar til að greina litningagerð fósturvefja í um 50 ár. Pær voru lengst af og fyrst og fremst framkvæmdar hjá konum eldri en 35 ára par sem líkur á litningafráviki aukast með aldri, ef saga var um fósturlát eða fæðingu par sem litningafrávik greindist eða ef fjölskyldusaga var um slíkt. Legvatnsástungur og síðar fylgjusýnitökur (samheiti: legástungur), hafa verið framkvæmdar á Íslandi í nær 40 ár. Pegar legvatnsástungur hófust hér á landi fæddu um 5\% íslenskra kvenna barn við eða yfir 35 ára aldri, en nú eru nær 17\% peirra sem eignast barn yfir pessum aldursmörkum. Konum sem óskuðu eftir legvatnsástungu fjölgaði hratt og pær voru orðnar rúmlega 500 árið 1996. ${ }^{1}$ Miðað við $1 \%$ líkur á fósturláti eftir legvatnsástungu, ${ }^{2}$ mátti rekja um 4-5 síðkomin fósturlát á ári einvörðungu til legvatnsástungu. ${ }^{3}$

Snemma á tíunda áratugnum birtust rannsóknir par sem lýst var hugsanlegri tengingu milli óeðlilega víðs ómsnauðs svæðis aftan á hnakka og hálsi fósturs á fyrsta priðjungi meðgöngu (kallað „aukin hnakkapykkt”) og litningafrávika. ${ }^{4-6}$ Með pví að skeyta saman í reikniforriti hnakkapykktarmælingu fósturs, aldri móður og upplýsingum um nokkra aðra áhættupætti, má fá áhættumat fyrir prjú algengustu litningafrávikin, prístæður 13, 18 og 21. Matið batnaði við að bæta við niðurstöðum varðandi péttni 2-3 lífefnavísa sem myndast í fylgju og mælast í móðursermi. Pessi skimun við lok fyrsta priðjungs meðgöngu kallast á íslensku sampætt líkindamat (first trimester screening). ${ }^{7}$

Frá árinu 1998 var farið að bjóða pessar mælingar og mat á áhættu á litningagöllum fósturs á Landspítala og síðar á Sjúkrahúsinu á Akureyri. Í upphafi var aðeins konum sem komu í viðtal vegna legvatnsástungu boðin hnakkapykktarmæling en kostir nýrrar aðferðar komu fljótt í ljós og 2006 var ákveðið að öllum punguðum konum stæði sampætt líkindamat til boða við 11-14 vikna meðgöngulengd óháð aldri. Ef skimunin bendir til aukinnar áhættu á litningafráviki er konum boðin greining með annaðhvort fylgjusýnitöku, sem hægt er að framkvæma frá 11 vikna meðgöngu, eða legvatnsástungu við 16-17 vikna meðgöngu, aðgerðum sem eru ekki með öllu án áhættu á fósturláti. Við fylgjusýnitöku eru teknar frumur úr fylgju og tekur tvo sólarhringa að fá bráðabirgðaniðurstöðu (lokaniðurstaða eftir 10-12 daga). Í legvatnsástungu eru teknir $10 \mathrm{ml}$ af legvatni og fæst niðurstaða eftir tvær vikur. Aðkallandi var að skoða hver áhætta við pessar aðgerðir væri hér á landi í samanburði við alpjóðlegar tölur og meta hvaða breytingar urðu samfara innleiðingu á sampættu líkindamati, meðal annars til að unnt væri að veita verðandi foreldrum sem íhuga legvatnsástungu eða fylgjusýnitöku haldgóðar upplýsingar til ákvarðanatöku, bæði um skimunina og greiningarrannsóknirnar.

\section{Efniviður og aðferðir}

Rannsóknin var afturskyggn og byggð á upplýsingum úr sjúkraskrám allra kvenna sem komu í legástungu á Landspítala á 10 ára tímabili frá 1. janúar 1998 til 31. desember 2007. Við gagnasöfnun var notuð skráning fósturgreiningadeildarinnar um pessar konur. Allar sjúkraskýrslur/mæðraskrár pessara kvenna voru skoðaðar, 
alls 2357 tilvik og par á meðal voru bæði konur sem fæddu barn og misstu fóstrið eða fóru í meðgöngurof vegna litningafrábrigða eða annarra fósturgalla. Samkeyrsla var við Fæðingaskráninguna á Íslandi til að sannreyna útkomu pungana og fá upplýsingar um fylgikvilla. Einnig var leitað á fæðingarstöðum utan höfuðborgarsvæðisins til að fá vitneskju um afdrif pungananna. Í Pjóðskrá mátti fá upplýsingar um konur sem höfðu flutt úr landi og fætt erlendis. Samtals voru 34 konur frá herstöðinni á Keflavíkurflugvelli. Ekki tókst að fá upplýsingar um útkomu meðgöngu peirra (1,4\%, sleppt í úrvinnslu).

Skráð voru aldur konu, ástæða fyrir legástungu, meðgöngulengd í dögum, hvort um fylgjusýni eða legvatnsástungu var að ræða, fjöldi fóstra, litningagerð fósturs, meðgöngulengd við fæðingu, sjálfkrafa eða framkallað fósturlát (meðgöngurof/fóstureyðing að lögum), andvana fæðingar og fósturgallar. Fósturlát miðast á Íslandi við skilmerki Alpjóðaheilbrigðismálastofnunarinnar að 22 vikna meðgöngulengd, en eftir pað er um fæðingu að ræða. Fósturlátstíðni með tilliti til ástunguaðferðar var miðuð við pau skilmerki, en fósturtap (fetal wastage) var einnig reiknað upp að 24 vikum, tíma sem almennt er talinn gefa til kynna að fóstrið geti lifað (fetal viability). Borin voru saman tvö 5 ára tímabil, 1998-2002 og 2003-2007, til að skoða áhrif breyttra ástunguaðferða með tilliti til ástæðu fyrir aðgerð og útkomu pungana.

Gögn voru vistuð í Microsoft Excel® forriti sem var varpaði yfir í SPSS forritið (Statistical Package for the Social Sciences, Chicago, Illinois, USA) vegna tölfræðireikninga. Notuð var lýsandi tölfræði til að skoða tíðni, en munur milli hópa athugaður með t-prófi fyrir óháð úrtak. Marktækni var miðuð við p-gildi <0,05.

Leyfi fengust frá Siðanefnd Landspítalans (erindi 35/2008), Persónuvernd (nr. 200804344) og framkvæmdastjóra lækninga á Landspítala.

\section{Niðurstöður}

Legástungur sem hægt var að fylgja eftir voru alls 2323, par af 78 í tvíburameðgöngum. Yfirlit um afdrif pungananna og meginástæður fyrir meðgöngurofi má sjá í töflu I. Í flestum tilvikum purfti tvær ástungur hjá tvíburum en hjá fjórum konum aðeins eina. Alls misstu 22 konur fóstur, par af ein tvíburamóðir. Fósturlátstíðnin hjá einburamæðrum var pví í heild 0,9\%, en 1,3\% hjá tvíburamæðrum. Af pessum konum hafði ein farið í leghálssaum skömmu fyrir ástunguna og kom 10 dögum seinna með sýkingu og dáið fóstur. Hjá annarri konu var fóstrið með mikinn vökvahjúp (fetal hydrops) pegar ástungan var gerð. Prjár konur misstu legvatnið en algengast var að fósturlátið uppgötvaðist í ómskoðun pegar ekki greindist hjartsláttur í næstu mæðra- eða ómskoðun við 17-19 vikna meðgöngulengd. Langflestar konurnar gengu með fóstur með eðlilega litningagerð. Algengasta litningafrávikið var prístæða 21 og síðan kynlitningafrávik. Prístæður 13 og 18 voru mun sjaldgæfari (tafla I). Heilbrigð börn sem fæddust eftir legástungu voru 2010 en 83 voru með sköpulagsgalla, einkum hjartaog nýrnagalla. Andvana fædd börn voru 18. Engin af fóstrum kvenna sem fluttu úr landi voru með litningafrávik. Rúm 7\% kvennanna völdu að fara í meðgöngurof/fóstureyðingu (n=174) og algengasta ástæðan var litningafrávik hjá fóstri eða meiriháttar sköpulagsgallar. Eftir stóðu 22 konur sem misstu fóstur fyrir 22 vikna meðgöngulengd.
Tafla I. Niðurstöður úr legástungum og afdrif meðgöngu 1998-2007.

\begin{tabular}{|c|c|}
\hline Heilbrigt barn & 2010 \\
\hline Andvana fædd & 18 \\
\hline Börn fædd með sköpulagsgalla & 83 \\
\hline Fæðing erlendis (eðileg litningagerð) & 16 \\
\hline Fósturlát eftir ástungu & 22 \\
\hline Fóstureyðing & 174 \\
\hline Litninga- og genafrávik* & 122 \\
\hline Prístæða 21 & 59 \\
\hline Prístæða 18 & 15 \\
\hline Prístæða 13 & 10 \\
\hline Kynlitningafrávik & 17 \\
\hline Prílitun og svipađir ágalla & 10 \\
\hline Aðrir erfðagallar & 11 \\
\hline Sköpulagsfrávik & 47 \\
\hline Hjartagallar & 9 \\
\hline Pvagfæragallar & 2 \\
\hline Pindarhaull & 5 \\
\hline Hygroma/hydrops & 5 \\
\hline Miðtaugakerfis- og útlímagallar & 26 \\
\hline Nýrnabilun móður & 1 \\
\hline Cytomegaloveirusýking móður & 1 \\
\hline Aðrar ástæður & 3 \\
\hline Samtals & 2323 \\
\hline
\end{tabular}

Í töflu II er sýnd fósturlátstíðni eftir pví hvor greiningaraðferðin var notuð, pað er að segja 0,8\% eftir legvatnsástungu og 1,3\% við fylgjusýnitöku. Munur milli aðferða við legástungu var ekki marktækur ( $\mathrm{t}=-0,913, \mathrm{df}=2321, \mathrm{p}=0,361)$. Ef miðað var við 24 vikna meðgöngulengd bættust við prjú tilvik kvenna sem misstu milli 22-24 vikna og tíðnin eftir legvatnsástungu (fósturtap/fetal wastage) fór í 1\% og eftir fylgjusýnatöku í 1,5\%. Blóðugt legvatn sást í 3,8\% tilvika og grænt/brúnleitt í 2,5\% tilvika. Fósturlátstíðnin við legvatnsástungu á fyrra tímabilinu var $0,9 \%$ og á pví seinna $0,7 \%$. Á fyrra tímabilinu var fósturlátstíðnin við fylgjusýnitöku 2,2\%, en $0,8 \%$ á pví síðara. Fósturlátstíðni hjá tvíburamæðrum við leg-

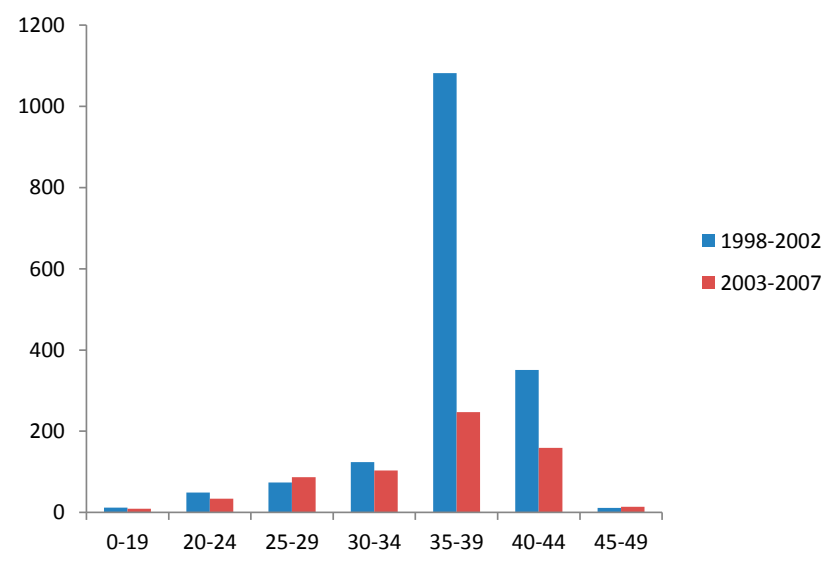

Mynd 1. Fjöldi kvenna eftir aldri sem komu í legástungu á tveimur 5 ára tímabilum. 
Tafla II. Fjöldi legástungna og fósturlátstíoni (\%) á Íslandi 1998-2007.

\begin{tabular}{lcc}
\hline & Legvatnsástunga & Fylgjusýni \\
\hline Fjöldi legástungna & 1775 & 549 \\
\hline Misstu fóstur miðað við 22 vikna meðgöngu & $15(0,8)$ & $7(1,3)$ \\
\hline Misstu fóstur miðað við 24 vikna meðgöngu & $17(1,0)$ & $8(1,5)$ \\
\hline
\end{tabular}

vatnsástungu var 1,4\%. Fylgjusýnitökur hjá tvíburum á pessum 10 árum voru eingöngu 7 hjá fjórum konum og engin peirra missti fóstur. Breyting varð á tíðni legvatnsástungna og fylgjusýnitöku milli fimm ára tímabila. Legvatnsástungum fækkaði en fylgjusýnum fjölgaði (tafla III).

Á fyrra tímabilinu var aldur meginástæða legvatnsástungu en á pví seinna hafði sampætt líkindamat fest sig í sessi, og fósturgreining pví færst framar í meðgönguna, pegar skimprófið reyndist jákvætt. Meðalaldur kvenna við legástungu var 36,9 ár (miðgildi 37 ár, staðalfrávik 4,1). Yfir allt tímabilið var meirihluti kvenna sem kom í legástungu á aldrinum 35-39 ára (n=1329; 56,4\%). Konur 40-44 ára voru 510 (21,6\%). Konur á aldrinum 45-49 ára voru 25 (1,1\%). Á aldursbilinu 30-34 ára voru 227 konur eða 9,6\%. Konur á aldrinum 25-29 ára voru 161 (6,8\%) og einungis rúm 4\% voru yngri en 25 ára. Á fyrra 5 ára tímabilinu var meirihluti kvennanna á aldrinum 35-39 ára (63,5\%), en á pví seinna var pessi aldurshópur $37,8 \%$. Dreifingin varð meiri milli aldurshópa eftir upptöku fyrsta priðjungs skimunar (mynd 1). Ástæður fyrir komu í legástungu breyttust á pessu tíu ára tímabili (mynd 2). Aldursástæðum fækkaði úr 81,2\% í 30,8\% milli fimm ára tímabila. Óhagstætt líkindamat var aðalástæðan fyrir legástungu á seinna tímabilinu eða hjá 46,8\%. Aðrar ástæður voru svipaðar milli tímabila.

\section{Umræða}

Tíðni fósturláta sem rekja mátti til legástungu var á pessu 10 ára tímabili tæplega $1 \%$ ef um einburapungun var að ræða en heldur hærri hjá tvíburum. Pessi niðurstaða er sambærileg við pað sem sést í öðrum löndum og sýnir að fylgikvillar eru óalgengir. Мeð breyttri aldurssamsetningu kvennanna, skimun sem býðst öllum konum og nýjum aðferðum hefur pessum inngripum fækkað verulega.

Af peim tæplega 2300 legástungum sem framkvæmdar voru hjá konum með einbura, missti 21 kona fóstur og af peim reyndist eitt vera með afbrigði við legástunguna og hefði sennilega dáið hvort eð var. Ein kona kom með sýkingareinkenni 10 dögum eftir ástunguna og var fóstrið pá dáið. Telja verður líklegt að sýking við ástunguna hafi orðið pess valdandi að fósturlát varð. Aðrar ástæður geta pví legið að baki fósturláti en ástungan sjálf. Goudry

Tafla III. Fjöldi legástungna og fósturlátstíoni (\%) á tveim fimm ára tímabilum.

\begin{tabular}{lcc}
\hline & $1998-2002$ & $2003-2007$ \\
\hline Fjöldi legvatnsástungna & 1499 & 276 \\
\hline Misstu fóstur (22 vikur) & $13(0,9)$ & $2(0,7)$ \\
\hline Fjöldi fylgjusýna & 182 & 367 \\
\hline Misstu fóstur (22 vikur) & $4(2,2)$ & $3(0,8)$ \\
\hline Fjöldi fæðinga & 20483 & 2134 \\
\hline
\end{tabular}

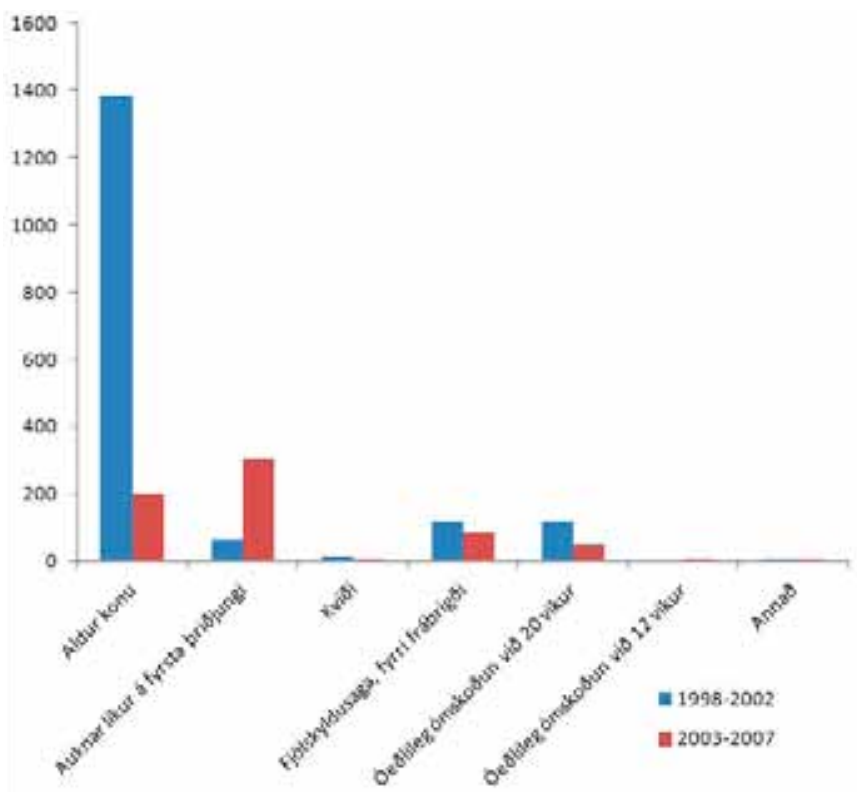

Mynd 2. Fjöldi kvenna sem fór í legástungu á tveimur 5 ára tímabilum ásamt ástæðu fyrir legástungum.

og félagar ${ }^{8}$ fylgdu eftir helmingi fleiri konum en hér var gert og töldu að í 6 tilvikum hefði legvatnsástungan ekki verið ástæða fósturlátsins. Álitamál getur verið hvaða tilfelli eigi að flokka sem fósturlát í kjölfar legástungu. Ekki pótti rétt hér að taka burt tvö fósturlát, pó pau hefðu líklega verið ótengd ástungunni.

Heldur fleiri konur misstu fóstur eftir fylgjusýnitöku en legvatnsástungu en tilvikin voru fá og munurinn var ekki tölfræðilega marktækur og gæti pví verið tilviljunum háður. Í erlendum rannsóknum hefur tíðnin verið heldur hærri eftir fylgjusýnitöku, en pað tengist einnig meðgöngulengd og pví að náttúrulegum fósturlátum fækkar eftir pví sem líður á meðgönguna.,10 Legvatnsástunga er að jafnaði gerð um einum mánuði seinna en fylgjusýnitaka. Með aukinni pjálfun í fylgjusýnitöku má ætla að tíðnin lækki. ${ }^{9}$ Varhugavert er að draga ályktanir um fósturlátstíðni hjá tvíburum af pessum gögnum, par sem fjöldi legástunga var lítill og aðeins varð eitt fósturlát í tvíburapungun. Hlutfall legástungna hjá tvíburum miðað við einbura var 1:55 eða svipað heildarhlutfalli einbura og tvíbura í landinu að meðtöldum tæknifrjóvgunum. Tvíburamæður virðast pví fara eins oft í legástungu og konur með einbura.

Viðmið um meðgöngulengd varðandi fósturlát í kjölfar legástungu hafa verið breytileg og ekki samstaða um hvað eigi að nota. Sumir hafa notað eina eða tvær vikur eftir ástunguna en aðrir vilja miða við 24 eða jafnvel 28 vikna meðgöngulengd. Petta torveldar samanburð milli rannsókna og landa. ${ }^{11}$ Við teljum rétt hér á landi eins og víða annars staðar að nota 22 vikur til að halda samræmi við skilmerki Alpjóðaheilbrigðismálastofnunarinnar um skil á mili fósturs og barns. ${ }^{12-14}$ Í nýlegum rannsóknum virðast pó flestir miða við 24 vikna meðgöngulengd og pví var tekið tillit til pess hér að auki.9,15,16 Í klínískum leiðbeiningum frá Royal College of Obstetricians and Gynaecologists í Bretlandi ${ }^{17}$ er viðmiðum skipt í prennt, pað er allt fósturtap og andvana fæðingar á meðgöngunni, missir innan 24 vikna og missir innan við 14 daga frá legástungu. Miðað við 24 vikna meðgöngulengd mundi fósturlátstíðnin hafa orðið sambærileg við flestar aðrar athuganir, einkum rannsókn Tabor og félaga9 sem spannaði 11 ára tímabil fyrir allar ástungur í 
Danmörku. Fósturlátstíðnin par var 1,4\% við legvatnsástungur og $1,9 \%$ við fylgjusýnitökur. Í nýlegu kerfisbundnu fræðilegu yfirliti ${ }^{10}$ var tíðni fósturláta við legvatnsástungur talin vera 0,9\% og eftir fylgjusýnitökur 1,3\% innan 24 vikna meðgöngulengdar. Íslensku tölurnar eru pví sambærilegar við erlendar tölur frá stöðum með mun fleiri tilvik, en sýna um leið að með pví að gera ástungurnar á aðeins einum stað á landinu næst ásættanlegur fjöldi aðgerða til að halda góðri færni allra sem koma að aðgerðinni.

Miklar breytingar áttu sér stað á pessu 10 ára tímabili sem rannsóknin nær yfir, par sem legástungum fækkaði umtalsvert en fylgjusýnitökum fjölgaði. Tíðni fósturláta lækkaði bæði eftir fylgjusýnitöku (úr 2,2\% 1 0,8\%) og legvatnsástungu (úr 0,9\% 1 0,7\%). Á fyrra tímabilinu framkvæmdu fjórir læknar legástungurnar en á síðara tímabilinu aðeins tveir. Margar erlendar rannsóknir sýna að betra er að legástungur séu framkvæmdar af fáum sérfræðingum sem hafa mikla reynslu og að með pví sé hægt að draga úr fósturlátstíðninni. ${ }^{918}$ Í leiðbeiningunum frá Royal College of Obstetricians and Gynaecologists er talið að hver sérfræðilæknir purfi að lágmarki 30 legástungur á ári til að viðhalda færni. ${ }^{17}$ Með tilkomu fyrsta priðjungs skimunar hefur legástungum fækkað umtalsvert. Hér á landi voru legvatnsástungur framan af framkvæmdar á Akureyri og á Landspítala en ákveðið var að hætta legvatnsástungum á Akureyri 2007 vegna pess hversu fáar pær voru. Fylgjusýnitökur hafa einungis verið framkvæmdar á Landspítalanum. Með pessu hefur fækkað peim stöðum par sem legástungur eru gerðar í samræmi við rannsóknarniðurstöður. ${ }^{9}$

Á rannsóknartímanum breyttust ástæður fyrir legástungum eftir að skimun varð í boði fyrir allar konur. Pessi 10 ár, 1998-2007, á meðan nýjar aðferðir voru innleiddar, voru tími breytinga par sem hratt dró úr legvatnsástungum en fylgjusýnitökum fjölgaði. Fósturgreining færðist framar á meðgönguna vegna sampætta líkindamatsins. Á seinna 5 ára tímabilinu, 2003-2007, var skimunin farin að festast í sessi sem viðbót utan hefðbundinnar meðgönguverndar hjá meginporra kvenna. Næmi prófsins er allt að 90\% og meira hjá eldri konum en peim yngri. ${ }^{19}$ Pví velja fleiri eldri konur en yngri að fara í legástungu, enda aukast líkur á litningafráviki með aldrinum. Danir innleiddu fyrsta priðjungs skimun á árunum 2004-2006 og urðu svipaðar breytingar hjá peim og á Íslandi og legástungum fækkaði par um helming. ${ }^{9}$ Á aldrinum 35-39 ára eru líkur á prístæðu 21, sem er algengasta litningafrávikið, frá 1:250 til 1:100. ${ }^{7}$ Með tilkomu fyrsta priðjungs skimunar greindust fleiri fóstur með litningafrávik en með færri inngripum. Skimunin varð pví markvissari og náði um leið til allra sem vildu piggja hana í stað mun minni hóps ef einungis var miðað við aldur, ${ }^{9}$ og sama breyting sást hér á landi.

Andvana fæðingar voru um 0,8\%, sem er nálægt almennri tíðni andvana fæðinga hér á landi á síðastliðnum fimm árum $(0,5 \%) .{ }^{13}$
Í peim tilvikum par sem andvana fæðing varð eftir að kona hafði farið í legástungu, tengdist pað afbrigðilegri niðurstöðu úr ómskoðun við 20 vikna meðgöngulengd eða síðar hjá priðjungi kvennanna. Hjá tveimur af pessum konum var hugsanlega hægt að rekja ástæðuna til afbrigðilegra líffræðilegra pátta í sampætta prófinu sem hafa tengst aukinni almennri meðgönguáhættu í fjölda rannsókna, jafnvel pegar niðurstöður litningaprófs voru eðlilegar. 7 Í tveimur tilvikum að auki var um tvíburameðgöngu að ræða par sem annar tvíburanna fæddist andvana. Líkur á missi í tvíburameðgöngu eru meiri en pegar um einburapungun er að ræða og litningafrávik eru algengari. ${ }^{16}$

Prístæður voru algengustu litningafrávikin eins og vænta mátti, eða hjá 3,6\% af pýðinu, og pá fyrst og fremst Down-heilkenni sem fannst í 2,5\% pungananna. Kynlitningafrávik voru rúmt $1 \%$, en önnur litningafrávik sjaldgæfari. Af peim rúmlega 170 konum sem völdu að enda meðgönguna var ástæðan oftast litningafrávik fósturs eða meiriháttar sköpulagsgalli sem fannst fyrr í meðgöngunni en unnt var að gera áður fyrr. ${ }^{20}$ Alls tóku 7\% kvennanna ákvörðun um að rjúfa meðgönguna vegna litningafrávika eða meiri háttar sköpulagsgalla í kjölfar greiningaraðgerðanna.

Á hverju ári stendur lítill hópur pungaðra kvenna og verðandi foreldra frammi fyrir peirri ákvörðun að piggja eða hafna boði um legástungu til að greina litningagerð fósturs í kjölfar jákvæðrar niðurstöðu úr fósturskimun á fyrsta priðjungi meðgöngu. Mikilvægt er að upplýsingarnar sem standa pessum konum til boða séu byggðar á gagnreyndri pekkingu og rannsóknum á aðstæðum og árangri á heimaslóð. Ráðgjöfin má pó ekki vera leiðandi. Klínískar leiðbeiningar um meðgönguvernd par sem lögð er áhersla á að pað sé val kvenna að piggja eða hafna rannsóknum, eru nauðsynlegar og tiltækar á Íslandi. Niðurstöður pessarar rannsóknar benda til pess að fósturlátstíðni í kjölfar legástungu sé sambærileg við pað sem best gerist erlendis. Mikil próun hefur átt sér stað á undanförnum árum á sviði fósturskimunar og fósturgreiningar, og verður eflaust áfram á komandi árum. Mikilvægt er að starfsfólk heilbrigðispjónustunnar fylgist vel með á pessu sviði og tileinki sér nýjungar sem byggðar eru á gagnreyndri pekkingu til að bjóða bestu pjónustu sem til er hverju sinni.

\section{Pakkir}

Dr. Viðari Halldórssyni hjá Félagsvísindastofnun Háskóla Íslands er pökkuð aðstoð við tölfræðilega úrvinnslu. Ljósmæðrafélag Íslands veitti Kristínu Rut Haraldsdóttur styrk vegna rannsóknarinnar. Guðrúnu Garðarsdóttur, ritara Fæðingaskráningarinnar, og Lilju Porsteinsdóttur, hjúkrunarfræðingi á Landspítala, er pökkuð aðstoð við gagnaöflun. 


\section{Heimildir}

1. Jóhannsson JH. Litningarannsóknir til fósturgreiningar Læknablaðið 2001; 87: 451-3.

2. Tabor A, Madsen M, Obel E, Philip J, Bang J, NörgaardPedersen B. Randomised controlled trial of genetic amniocentesis in 4606 low-risk women. Lancet 1986; 1 1287-93.

3. Harðardóttir H. Próun fósturgreiningar. Læknablaðið 2001; 87: 399-400

4. Cullen MT, Gabrielli S, Green JJ, Rizzo N, Mahoney MJ, Salafia, C, et.al. Diagnosis and significance of cystic hygroma in the first trimester. Prenat Diagn 1990; 10: 643-

5. Nicolaides KH, Azar G, Byrne D, Mansur C, Mark K. Fetal nuchal translucency: ultrasound screening for chromosomal defects in first trimester of pregnancy. BM] 1992; 304: 867-9.

6. Szabo J, Gellen J. Nuchal fluid accumulation in trisomy-2 detected by vaginal sonography in first trimester. Lancet 1990; 336: 1133

7. Nicolaides KH, Sebire NJ, Snijders RJM. The 11-14 seek scan. The diagnosis of fetal abnormalities. Parthenon Publishing Group, New York 1999

8. Gaudry P, Grange G, Lebbar A, Choiset A, Girard S, Goffinet $\mathrm{F}$, et.al. Fetal loss after amniocentesis in a series of 5,780 procedures. Fetal Diagn Ther 2008; 23: 217-21.
9. Tabor A, Vestergaard $\mathrm{CH}$, Lidegaard O. Fetal loss rate after chorionic villus sampling and amniocentesis: an 11-year national registry study. Ultrasound Obstet Gynecol 2009; 34: 19-24

10. Mujezinovic F, Alfirevic Z. Procedure-Related Complications of Amniocentesis and Chorionic Villous Sampling: A Systematic Review. Obstet Gynecol 2007; 110: Samplin:

11. Tabor A, Alfirevic Z. Update on Procedure-Related Risks for Prenatal Diagnosis Techniques. Fetal Diagn Ther 2010; 27: 1-7.

12 Lög um fæðingar- og foreldraorlof nr. 95/2000. Andvana fæðing og fósturlát. althingi.is

13. Bjarnadóttir RI, Garðarsdóttir G, Smárason AK, Pálsson GI. Skýrsla frá Fæðingaskráningunni fyrir árið 2010. Kvennadeild og vökudeild Barnaspítala Hringsins, Landspítali Háskólasjúkrahús, Reykjavík 2011.

14. Lander T. Neonatal and perinatal mortality: country, regional and global estimates 2006. World Health Organization 2006.

15. Cahill AG, Macones GA, Stamilio DM, Dicke JM, Crane JP, Odibo AO. Pregnancy loss rate after mid-trimester amniocentesis in twin pregnancies. Am J Obstet Gynecol 2009; 200: 257, e1-6.
16. Simonazzi G, Curti A, Farina A, Pilu G, Bovicelli L, Rizzo $\mathrm{N}$. Amniocentesis and chorionic villus sampling in twin gestations: which is the best sampling technique? Am J Obstet Gynecol 2010; 202: 365.

17. Royal College of Obstetricians and Gynaecologists. Amniocentesis and chorionic villus sampling. Green-top Guideline nr. 8. June. RCOG Press, London 2010.

18. Cebesoy FB, Balat O, Pehlivan S, Kutlar I, Dikensoy E, Ugur MG. Is pregnancy loss after amniocentesis related to the volume of amniotic fluid obtained? Arch Gynecol Obstet 2009. 279: 357-60.

19. Marttala J, Ranta JK, Kaijomaa M, Nieminen P, Laitinen P, Kokkonen $\mathrm{H}$, et. al. More invasive procedures are done to detect each case of Down's syndrome in younger women. Acta Obstet Gynecol Scand 2011; 90: 642-7.

20. Grande M, Arigita M, Borobio V, Jimenez JM, Fernandez S, Borrell A. First-trimester detection of structural abnormalities and the role of aneuploidy markers. Ultrasound Obstet Gynecol 2012; 39: 157-63.

ENGLISH SUMMARY

\section{Fetal loss after amniocentesis and chorionic villus sampling in Iceland}

Kristin Rut Haraldsdottir, Helga Gottfredsdottir, Reynir Tomas Geirsson

Introduction: Amniocentesis and chorionic villus sampling (CVS) are methods for fetal chromosomal diagnosis. Pregnant women aged $\geq 35$ years have been offered amniocentesis in Iceland for over 35 years. The main testing indication was maternal age until 1998, when universal early screening was introduced. We examined outcome and fetal loss following amniocentesis and CVS in singleton and twin pregnancies, age distribution changes, reasons for the procedures and fetal karyotype diagnoses.

Material and methods: Retrospective quantitative study on women who had amniocentesis and CVS $(n=2323)$ in the Prenatal Diagnosis Unit at Landspitali University Hospital during 1998-2007. Unit files and individual case and maternity records were used to retrieve information on the indications and on maternal age, type of procedure, outome of pregnancy, and the fetal karyotype.
Results: The number of procedures was substantially reduced from over 500 to just over 100 per year, with a proportional shift to CVS. Procedure-related fetal loss was 22/2323 (0.9\%), with no significant difference between amniocentesis $(0.8 \%)$ and CVS $(1.3 \%)$. The difference decreased in the latter half of the study period to $0.7 \%$ and $0.8 \%$, respectively. Age-related reasons decreased from $81.2 \%$ to $30.8 \%$. Conclusion: The fetal loss incidence rates indicated that amniocentesis and CVS have the same safety level as elsewhere. Complications were uncommon. With CVS fetal screening was moved to an earlier time in pregnancy. Early screening has changed the maternal age profile and is available to all women on request. The information obtained can be used to improve service information.

Keywords: Amniocentesis, chorion villus sampling, miscarriage, fetal loss, singelton pregnancy, twins.

Correspondence: Kristín Rut Haraldsdóttir, krruthar@landspitali.is

${ }^{1}$ Faculty of Nursing, Department of Midwifery, University of Iceland, ${ }^{2}$ Women's Clinic, Landspitali University Hospital, ${ }^{3}$ Faculty of Medicine, University of Iceland, Reykjavik, Iceland. 